\title{
The art of crowdfunding arts and innovation: the cultural economic perspective
}

\author{
Christian Handke ${ }^{1}$ (D) $\cdot$ Carolina Dalla Chiesa $^{1}$ (D)
}

Received: 16 December 2020 / Accepted: 24 January 2022 / Published online: 28 February 2022

(c) The Author(s) 2022, corrected publication 2022

\begin{abstract}
Crowdfunding is an innovation from the cultural sector that has found broad applications in other aspects of the economy. We document that cultural economics provides a refined structure to explain much of the crowdfunding phenomenon, which will be useful for any research on this topic. Based on central themes of cultural economics (including quality and demand uncertainty, socially interdependent demand formation, public good attributes, and intrinsic motivation to create), we extend on the current understanding in the crowdfunding literature regarding three fundamental questions: (1) under what circumstances is crowdfunding a superior alternative to traded means of financing innovative projects? (2) What types of crowdfunding are best suited for specific (cultural and creative) industries (CCI)? (3) What is the potential of crowdfunding for cultural and creative industries? Overall, we describe crowdfunding as a flexible tool for mitigating various, fundamental challenges in CCI and beyond. We also identify limitations of crowdfunding, which for now, severely restrict its application. Arguably, the main boon of crowdfunding for cultural economics is not so much that it makes markets (for cultural products) much more efficient and fosters growth. Instead, crowdfunding enables sophisticated empirical research on central topics of cultural economics, and a rich and diverse literature has begun lifting that treasure.
\end{abstract}

Keywords Crowdfunding $\cdot$ Cultural industries $\cdot$ Creative industries $\cdot$ Cultural economics, arts funding · Innovation funding

JEL Classification L26 · O31 · Z10 · D26

Christian Handke

handke@eshcc.eur.nl

Carolina Dalla Chiesa

dallachiesa@eshcc.eur.nl

1 Erasmus School of History, Culture and Communication (ESHCC), Erasmus University Rotterdam, Room M7-18, P.O. Box 1738, 3000 DR Rotterdam, The Netherlands 


\section{Introduction}

This paper discusses crowdfunding - calls to a broad public for the provision of financial resources to support the development of a specific, novel good or servicefrom a perspective of cultural economics. The first online crowdfunding platform, ArtistShare launched in 2001, was specialized in the cultural sector (Boeuf et al., 2014; Bradley \& Luong, 2014; Dalla Chiesa \& Handke, 2020). By now, crowdfunding is applied for many types of projects, but cultural and creative industries (CCI) continue to be one of the most important areas for applications of crowdfunding (Agrawal et al., 2015; Bürger \& Kleinert, 2020; Hobbs et al., 2016; Mendes-da-Silva et al., 2016; Mollick, 2014). ${ }^{1}$ Crowdfunding is a case in point where the cultural sector has spawned an innovative business idea with much wider applications, which makes crowdfunding an important topic for cultural economics.

A burgeoning literature on crowdfunding has employed various aspects of economic theory-such as signaling theory (Colombo, 2021) or two-sided markets (e.g., Viotto da Cruz, 2018)_and has yielded extensive empirical evidence on success factors of crowdfunding calls, as well as appropriate business models for crowdfunding platforms. This paper develops a different perspective. On the one hand, it concentrates on creators of cultural products and on the predominant crowdfunding practices that have been employed to finance cultural production. On the other, it harnesses general themes in cultural economics to start illuminating three fundamental and related questions, which are surprisingly unexplored so far:

1. Under what circumstances is crowdfunding a superior alternative to traded means of financing innovative projects?

2. What types of crowdfunding are best suited for specific CCI?

3. What is the potential of crowdfunding for CCI?

Overall, we conclude that crowdfunding is a sophisticated and flexible tool for mitigating various, fundamental problems in CCI, but it has clear limitations, which severely restrict its application. Nevertheless, the shifting of restrictions for participants in markets for cultural and creative products, which crowdfunding entails, brings great opportunities to learn about CCI.

\section{Typical features of crowdfunding via online platforms}

This entire paper focuses on crowdfunding via online platforms. To be sure, financing-specific production projects by means of open calls for financial contributions have a long history offline. The financing of the pedestal of the Statue of

\footnotetext{
1 In terms of total funding raised and the number of projects supported, Belleflamme et al. (2015) observed approximately exponential growth patterns in crowdfunding since the noughties. According to Ziegler et al. (2021), in the year 2020 crowdfunding of any type has raised revenues of over 12 billion US\$ in total.
} 
Liberty - by a call for donations in newspapers - is an example of crowdfunding before the emergence of online platforms (Gras et al., 2017). Nevertheless, the contemporary expression "crowdfunding" is predominantly associated with the Internet and online platforms.

Figure 1 depicts the main, typical elements and the process of a crowdfunding campaign via an online platform. A so-called founder comes up with a project and feeds the information on the crowdfunding call for this project into a template provided by the platform. Issues covered in the call are a description of the project and its founders in text, images, or video, any funding goal required to commence with the project, the time period in which the call will be open, and any rewards for backers. The platform files the call into its database and includes it into its recommendation system that determines in what sequence calls appear for visitors of the website. The platform also provides standardized contractual terms-possibly with some preset options for the founder to choose-which should reduce bargaining costs and the potential for mistrust and conflict between founders and backers. Backers can access the information on many projects on the site and get to choose to which projects they want to pledge any funding. The crowdfunding platform receives the money and forwards the total amount pledged by all backers to the founder, or reimburses the backers in case the call does not reach its funding target. Successful projects then go ahead. All the while, backers often use other communication channels to inform themselves about founders and their activities or to interact with them, for instance via social media.

Some crowdfunding raises donations only and the founder does not provide any quid pro quo to backers. In the case of reward-based crowdfunding, the backers receive some non-monetary good or service, for instance attribution, some involvement in the project, or preferential access to events or works produced. In equitybased crowdfunding, the founder pays backers subject to the terms of the investment, which usually depends on success metrics, so that some of the entrepreneurial risk is taken on by the backers.

To finance themselves, crowdfunding platforms usually keep a share of the total amount of funds pledged by backers to a project, usually between five and fifteen percent. ${ }^{2}$ As is typical for online platforms in two- or multi-sided markets (Armstrong, 2006; Rysman, 2009), today crowdfunding platforms do not charge substantial initial fees for participants, nor do they invest in projects themselves. ${ }^{3}$ On the one hand, this helps avoid conflicts of interest between the platform and either founders or backers. On the other hand, this helps platforms expand the number of participating founders and potential backers. They can thus exploit economies of scale by spreading fixed costs over a larger range of activities. They can also exploit network effects and thus the appeal of their platform for backers and founders and their competitiveness (Belleflamme et al., 2018). Crowdfunding does not by definition require

\footnotetext{
${ }^{2}$ Exceptions are common in donation-based crowdfunding and platforms, which often waive the platform fee for specific calls to stimulate donations.

3 Typically, large platforms such as Kickstarter hardly screen or curate calls, except for apparent cases of law infringements.
} 


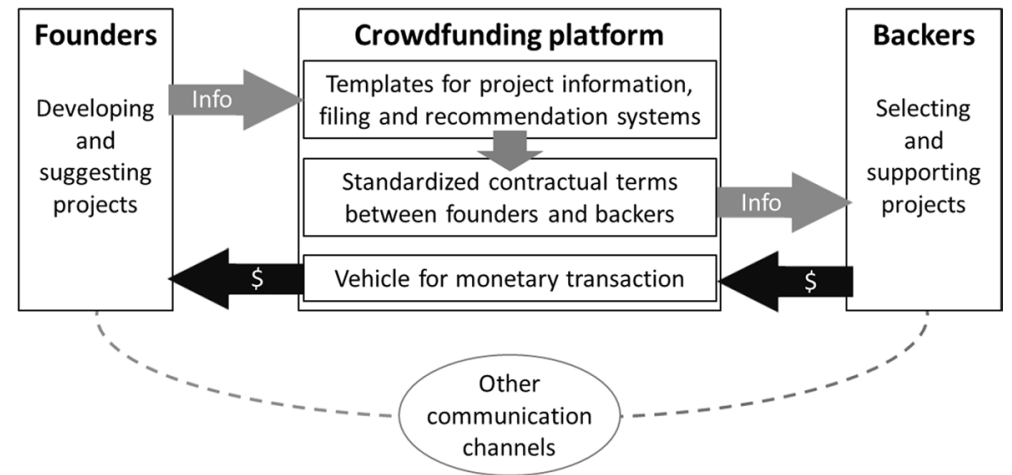

Fig. 1 The process of crowdfunding via a platform. Sources: Dalla Chiesa and Handke (2020)

an online platform. For instance, individual artists have used their own websites to invite financial support for projects. But today, crowdfunding largely occurs via online platforms.

\section{A short history of crowdfunding platforms and models, and typical aspects of $\mathrm{CCl}$ crowdfunding}

This section documents more specific features of crowdfunding in CCI. Important crowdfunding platforms are listed in Table 1 in chronological order of their foundation.

ArtistShare, an early online crowdfunding platform created for cultural projects, was innovative in providing an opportunity to mix various rewards (such as tickets, free copies of works produced, or meetings with the artist). Today, this is the norm among many popular crowdfunding platforms. Like most CCI crowdfunding sites, ArtistShare also adopted an All-or-Nothing (AON) setup, where calls specify a minimum funding target and backers are reimbursed in case this target is not met over the time period of the call. Keep-it-All (KIA) setups, without reimbursement of backers, are rare in CCI crowdfunding. In 2006, Sellaband launched to help musicians without a record deal to finance albums, for instance. It used royalty crowdfunding, where backers/investors participate in profits from creative projects (Agrawal et al., 2015). Sellaband ceased operating in 2015. Kickstarter launched in 2009 with a novel mode of financing itself by keeping a share of the revenues generated by successful projects. In this case, the interests of founders and the platform are aligned, and the risk of founders is reduced. During the same year, Indiegogo started offering KIA setups, in which a founder receives pledged funds even if the goal set by the project is not reached.

Initially, most calls on Indiegogo and Kickstarter regarded cultural projects on the fine arts, comics, dance, design, fashion, film and video, music, photography, creative writing, and theater. Famous campaigns, which resulted in popular works, include award-winning films, such as the Egyptian production "The Square" 
(depicting the so-called Arab Spring protests in 2013), "Wish I Was Here" by director/lead actor Zach Braff, and the animation "World of Tomorrow" that won the Grand Jury Prize at Sundance film festival in 2015 (Indiewire, 2017). Another major success on Kickstarter was the tabletop game "Cards Against Humanity." Kickstarter has remained mostly focused on creative industries and tech innovations. Indiegogo has tried to expand its scope even further and now hosts additional special categories such as "community projects," "health" and "food/beverages," among others. Indiegogo also introduced equity-based campaigns in 2016 but abandoned that option three years later. ${ }^{4}$

Since 2009, many new platforms with varying models have been launched (Cumming \& Hornuf, 2018). Symbid in the Netherlands, for instance, is specialized on equity-based crowdfunding. Kiva is an example of a peer-to-peer (P2P) lending platform, where founders commit to paying back regardless of the pecuniary success of the project, similar to a conventional loan. Nevertheless, Allison et al. (2013) show that on this site, backers/lenders accept terms that are not competitive with other types of financial investments, and thus seem motivated by charity at least in part. Since 2013, Patreon popularized subscription-based crowdfunding version, where backers make payments at regular intervals to continuously support a founder over various projects (Regner, 2020; Swords, 2017).

This inevitably sketchy history entails three initial, important points for the rest of this paper. First, reward-based crowdfunding and AON setups are the norm in crowdfunding of cultural production today. ${ }^{5}$ We thus focus on this type of crowdfunding and seek to explain its predominance. Nonetheless, there has been some experimentation with various other aspects of crowdfunding. Subject to their particular circumstances, potential founders of cultural projects get to choose between various setups offered by various platforms (cf. Rykkja et al., 2020).

That relates to our second point: conditions differ across the CCI and between specific stakeholders within them, which is bound to affect the benefits of crowdfunding relative to other means of financing cultural production. For instance, crowdfunding allowed many newcomers and niche artists to finance projects. The capacity of crowdfunding to mitigate superstar effects in cultural industries should not be exaggerated, however (Cameron, 2016). So far, it is hard to find any current superstar creators, who would have started their career with crowdfunding. Wellestablished creators enjoy massive advantages in crowdfunding, too (Barzilay et al., 2018). Celebrities like Sylvester Stallone, David Fincher, Spike Lee, Neil Young, and the Pixies have successfully raised money on Kickstarter. Regarding different

\footnotetext{
${ }^{4}$ Crowdfunding campaigns on technological innovation, which raised millions of US\$ with both reward and equity-based crowdfunding, were for the "Oculus Rift" virtual reality headset, for Waka Waka solar panels, (Cholakova \& Clarysse, 2015), or for the Pebble smartwatch (Ganatra, 2016).

5 For instance, founders of video game projects routinely reward backers with within-game perks, such skins and gadgets, and/or with access to the game without a subscription fees; the widely acclaimed "Star Citizen" game is a case in point. Furthermore, Brzozowska and Galuszka (2021) document that independent musicians often combine preferential or rebated access to performances and free access to digital recordings as rewards for backers.
} 


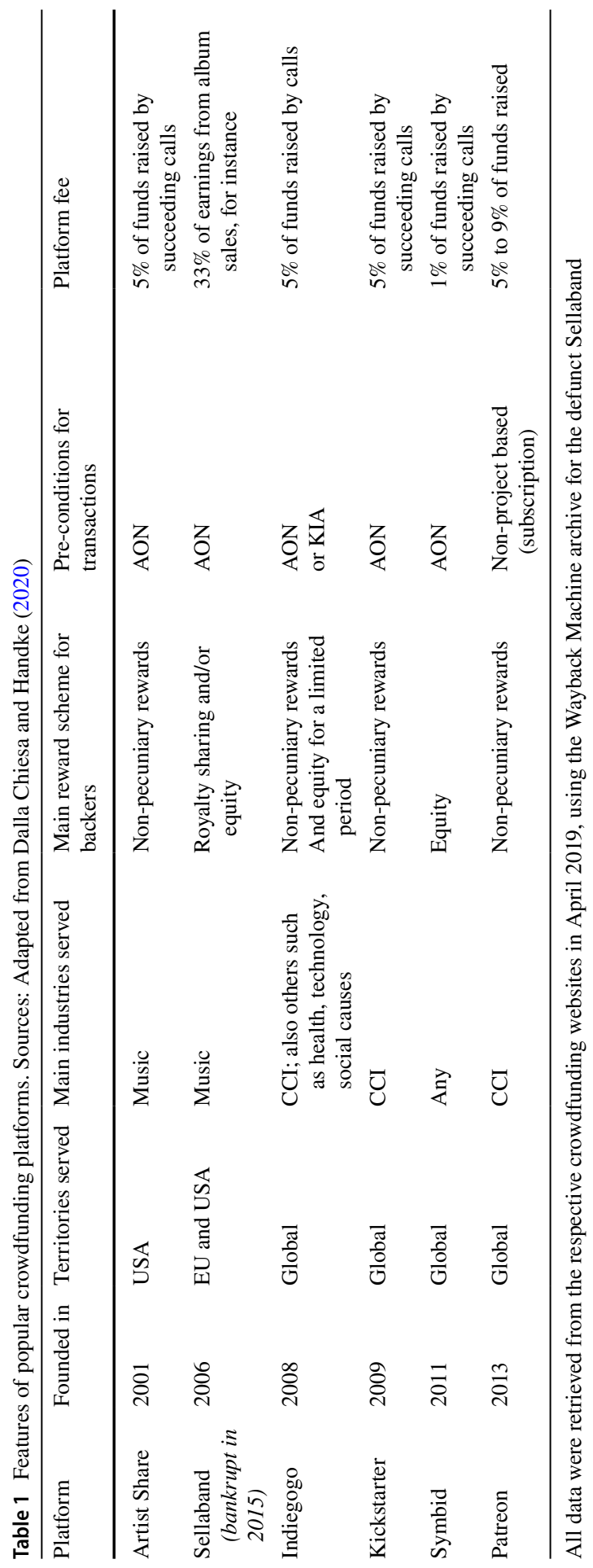


categories of creative works, there are also noteworthy differences. For instance, a widely cited early study by Mollick (2014) documents that on Kickstarter, crowdfunding calls for games, design, technology, have had relatively high success rates (on games, see also Bidaux, 2020).

Third, crowdfunding probably needs to be adapted to specific circumstances. A crowdfunding set-up that maximizes the probability of success for a superstarendorsed movie project may not do so for a newcomer in the fine arts, for example. The issue of selective matching of crowdfunding options to specific circumstances has not received much attention in the burgeoning literature on crowdfunding success factors; see for instance the recent Butticè and Ughetto (2021) or Shneor and Vik (2020).

In the following, we work out falsifiable propositions regarding the efficient matching of crowdfunding options, as well as the efficient scale and scope of crowdfunding subject to this, across the various cultural industries.

\section{Crowdfunding in cultural economic terms}

There is a rich and diverse empirical literature on crowdfunding across the social sciences (Moritz \& Block, 2016), which often makes inductive use of theory. Extensive data on crowdfunding are available in reports by the European Commission (De Voldere \& Zeqo, 2017) and by the Cambridge Center for Alternative Finance (e.g., Ziegler et al., 2018, 2021). Regarding economic analyses in a narrow sense, Agrawal et al. (2014) provide an overview, which relates early empirical results to economic theory. Belleflamme et al. (2015) present a broad and thorough, mostly informal, discussion that harnesses central concepts in industrial organization theory and focuses on crowdfunding platforms. Hudik and Chovanculiak (2018) discuss crowdfunding as a means for the private provision of goods with public good attributes. Belleflamme et al. (2019) and Chang (2020) present recent formal economic models. Both articles assume differentiated willingness to pay among a mass of users due to incomplete and/or heterogenous information. They both focus on rewardbased crowdfunding. A comprehensive literature review is beyond the scope of this paper. Instead, we identify central topics in the crowdfunding literature, and relate each of them to central topics in cultural economics. ${ }^{6}$ This is one unique contribution of this paper.

The economic literature on CCI identifies shared characteristics of these industries, the combination of which may set the CCI apart from other aspects of the economy. We invoke eight main themes in cultural economics to explain crowdfunding practices: (1) a cost structure with high fixed development costs and relatively low marginal costs of supplying existing creative goods to additional users; (2) demand uncertainty; (3) differentiated products and differentiated preferences; (4) experience good attributes of creative works; (5) public good attributes of creative

\footnotetext{
6 We do not address platforms' two-sided (or multi-sided) market strategies. See Belleflamme et al. (2015) and Viotto da Cruz (2018) on this topic.
} 
works; (6) socially interdependent demand formation; (7) intrinsic motivation to create; as well as (8) diverse values of creative works and crowding effects. This is a tricky exercise, since CCI differ from each other, say recorded music and performing arts. Furthermore, there are some chicken-and-egg problems: it is hard to distinguish fundamental characteristics from their consequences. However, for our purposes it is sufficient to establish that many economic characteristics of CCI are associated with market failure, and that many practices in CCI can be explained as efforts to mitigate the corresponding problems. We see crowdfunding as a case in point. Where crowdfunding offers more efficient solutions than traded means of financing creativity, it will reduce allocative inefficiencies and/or promote cultural diversity.

\subsection{Cost structure conundrums: covering up-front costs and divesting risk}

The typical production function of CCI features high, and at least partially sunk, costs of creation combined with relatively low and often non-increasing marginal costs of providing additional users with access to existing products. ${ }^{7}$ Furthermore, some aspects of cultural products are durable: they hardly physically deteriorate, so that there is the potential for revenues to suppliers over extended periods of time (Caves, 2000). Thus, like any supplier of innovative products, suppliers of cultural products face the challenge to raise up-front finance to cover development costs in return for delayed (and uncertain) rewards in the future. Crowdfunding is a means to mitigate that problem.

Successful crowdfunding calls make funds available to founders before they incur the costs of creation. Crowdfunding may thus enable production, where creators are not otherwise able to cover up-front costs. Crowdfunding also allows founders to shift some of the inevitable entrepreneurial risk they are subjected to due to demand uncertainty onto backers. ${ }^{8}$ In other words, crowdfunding allows for risk pooling among stakeholders. Perhaps even more importantly, crowdfunding helps reduce uncertainty and risk for founders/creators (see Sect. 4.2) and, if done right, for backers (Sect. 4.4).

\subsection{Demand uncertainty for creators: testing the market and building reputations}

It is notoriously difficult to predict demand for creative works before the finished good is released to market (Caves, 2000). Even after market release, demand for specific works tends to wax and wane in fads and fashions, which are hard to predict (Kretschmer et al., 1999).

\footnotetext{
${ }^{7}$ Digitalization tends to lower fixed costs of producing cultural works of a given quality (Handke, 2006, 2012; Liebowitz \& Watt, 2006; Waldfogel, 2012a, b; 2017). However, some non-negligible costs of creation remain, and the competitive quality of works may change, as many suppliers exploit new opportunities due to digitalization.

${ }^{8}$ While demand is uncertain, the maximum losses for investors are limited by their financial outlay. Thus, there is thus a reasonably well-defined pecuniary risk.
} 
Crowdfunding provides creators with a means to test the market before all production costs are incurred: the success of the call provides them with valuable (but still imperfect) information on the prospective demand for any finished goods, or the willingness to contribute to the provision of goods (Viotto da Cruz, 2018). In a sense, each crowdfunding call constitutes a choice experiment, even though these are subject to strategic actions by stakeholders in the face of assurance problems and the potential for free-riding (see Sects. 4.5 and 4.6). Over several calls, suppliers of cultural products may also employ crowdfunding as contingent valuation experiments, which has been a prominent empirical method in cultural economics (Angelini \& Castellani, 2019; Handke et al., 2016; Noonan, 2003; Seaman, 2020).

Furthermore, Belleflamme et al. (2015) and Brown et al. (2017) see crowdfunding calls as marketing tools, which reach out to potential contributors and customers and engage them. Successful crowdfunding campaigns may also promote the reputation (or brand) of founders and their projects in the wider public. Even after a crowdfunding call has run its course, any apparent success also provides signals of quality to other investors. For instance, some cultural policy makers have started considering crowdfunding results when allocating funding to specific cultural organizations or projects (so-called matchfunding; Baeck et al., 2017; Senabre \& Morell, 2018). ${ }^{9}$

\subsection{Differentiated products and users: price discrimination as a key crowdfunding benefit for founders}

Cultural products are differentiated. Suppliers are in monopolistic competition based not only on price but also on product attributes. Suppliers of differentiated products enjoy some, albeit limited, market power. Users are also differentiated in their preferences. Furthermore, users exhibit taste for variety: over time, they use several product variants and preferences change with use, because users seek novelty and surprise (Bianchi, 2002) or because of taste formation (Blaug, 2001; Seaman, 2006). This leaves ample scope for price discrimination, where suppliers can obtain sufficient information on users' willingness to pay (WTP).

Crowdfunding calls entice users to reveal information on their WTP. Thus, regarding founders' benefits, price discrimination is central in the economics literature on crowdfunding.

Belleflamme et al. (2019) emphasize "menu pricing." They assess crowdfunding as a means to improve the quality of an existing product. Founders charge a "pre-order" price to backers for the improved product at the crowdfunding stage and another price at the retail stage. Regular customers are charged a different price at the retail stage. ${ }^{10}$

\footnotetext{
9 As discussed in Sect. 4.6, crowdfunding as an alternative source of finance has ambiguous effects on incentives for other investors, buyers, or donors, and thus the revenue mix of CCI. Crowdfunding may also affect creators' other fundraising and marketing activities. See Andreoni and Payne (2003), who demonstrate that creators receiving government grants reduce other fundraising activities.

10 Belleflamme et al. (2019) also see crowdfunding as a means to foster demand: "[...] crowdfunding allows to find new contributors and therefore future customers before the release of the product on the market. Brands under development may enjoy early funding and consumers may benefit from a lower
} 
In Chang (2020), a set of backers with differentiated quality signals each decide "whether to contribute to a project in return for a unit of the good the project aims to produce." In the formal model, users either fund the reward-based call at the crowdfunding stage or purchase the finished good at the retail stage. Crowdfunding offers suppliers an opportunity to price discriminate (group pricing), by charging users with a high-value signal a higher price at the crowdfunding stage. ${ }^{11}$

However, crowdfunding campaigns usually give backers some control over the amounts they pledge. Backers do not just make a binary decision whether to pledge a fixed amount. There may be minimum thresholds to cover marginal transaction costs or to trigger any rewards. But backers have the option-and often use the option-to pledge amounts exceeding any minimum thresholds. Thus, crowdfunding does not only offer opportunities for group pricing (third degree price discrimination) or menu pricing (second degree price discrimination). Crowdfunding also enables personalized pricing (first degree price discrimination), albeit to a limited extent. The discussion of the issue requires more preparation, and we return to it in Sect. 4.5.

\subsection{Incomplete information of users: experience good attributes, quality uncertainty, asymmetric information, and crowdfunding as a commitment tool}

From the perspective of users, cultural products have experience good attributes (Ginsburgh \& Throsby, 2006; Nelson, 1970; Towse, 1997). Users make any purchasing decisions based on limited information regarding (1) product qualities and (2) the full range of options available, in particular concerning the qualities of other cultural products with experience good attributes, which may be close substitutes.

\subsubsection{Quality uncertainty}

Much of the literature on crowdfunding discusses incomplete information on the backer side. Compared to retailing of finished goods as a means to finance production, at the crowdfunding stage users have less information than at any subsequent retailing stage. At the crowdfunding stage, (1) the finished good is not yet available for inspection, and (2) no signals of quality from certifiers or other users having inspected the finished goods are available, either. Of course, the call itself is a means to make information on a production project available to users, but founders can-and have incentives to-provide biased information that users cannot verify.

\footnotetext{
Footnote 10 (continued)

price during the launch period of the product or brand. Crowdfunding opens the possibility to "engage" the brands with their contributors and may stimulate the demand for the product."

11 Chang (2020) assumes risk-aversity of all market participants, but includes some costs for crowdfunding for the founder ("information rents" the founder has to offer).
} 
Adhering to the standard assumption of risk-aversity and positive discount rates with delayed benefits, as a rule we expect that users' average WTP (or pledge) at the crowdfunding stage will be lower than at a retailing stage.

\subsubsection{Asymmetric information and quality signals}

Belleflamme et al. (2015) address moral hazard ("hidden actions"), where founders have limited incentives to reveal valid information to backers and to invest in product quality, once the call has succeeded. ${ }^{12}$ Thus, a main theme in the empirical-economic literature on crowdfunding is the factors determining the success of calls_-usually measured either by the amount pledged or by whether funding goals were reached-in spite of asymmetric information. ${ }^{13}$

First, the description of the project in the call itself entails useful information. For instance, in their study of P2P-lending, Allison et al. (2015) show that verbal references to intrinsic motivation by the founders in the call tend to increase pledging. The linguistic style seems to matter more for "social projects" than purely commercial ones (Parhankangas \& Renko, 2017). The apparent effort made by founders with the call description, or evidence provided of prior investments made by other parties, should provide signals that increase backers' propensity to pledge.

Second, information on the personal characteristics of founders may affect crowdfunding success. This information may come from the call description (Kim et al., 2016) or from other channels of information, such as social media or even personal interactions. Extensive empirical work has documented cases where crowdfunding thrives on existing communities involving founders and potential backers and that crowdfunding can foster such communities (Zheng et al., 2014; Colombo et al., 2015; Galuszka \& Browzowska, 2017; Josefy et al., 2016). Early backers are often personal acquaintances of founders (Gerber et al. 2016). Several studies address factors such as gender and other personal characteristics of entrepreneurs and how they are associated with funding success, compared to other methods of raising finance from banks or venture capital (e.g., Barasinska \& Schäfer, 2014; Gorbatai \& Nelson, 2015; Marom et al., 2016; Younkin \& Kashkooli, 2016). Crowdfunding seems to have relative advantages for females (Gorbatai \& Nelson, 2015). Additionally, Agrawal et al. (2015), Mendes-Da-Silva et al. (2016) and Breznitz and Noonan (2020) document some positive effects of geographical proximity between founders and backers on crowdfunding success.

Third, information on the past performance of creators should affect crowdfunding success. This reputation information will usually be available from other, less biased, sources than the call description provided by the founder in the template

\footnotetext{
12 Arguably, there is also scope for adverse selection: opportunistic creators may use crowdfunding calls to exploit the limited information and lower information processing capacity of private individualscompared to patrons in work-for-hire or to specialized investors-and relegate inferior projects to crowdfunding (cf. Mollick \& Nanda, 2016).

13 Belleflamme et al., (2015) also discuss several means available to platforms to mitigate moral hazard. None of these are at all likely to entirely resolve the matter, since platforms themselves have limited information and divergent interests from backers.
} 
determined by the platform. Mollick (2014) shows that the size of the network of founders, in particular on social media, is positively associated with the success of crowdfunding calls (cf. Calic \& Mosakowski, 2016; Clauss et al., 2018).

Finally, providing free or easy access to finished goods may serve as a documentation tool, even if backers pledge for other reasons: backers hereby receive information on the conduct of the founder and quality of finished goods. In CCI, there is typically hardly any recourse based on later negative assessments of product quality after investment or purchasing (Kretschmer et al., 1999). However, providing information on quality to backers ensures that founders need to take reputational effects into account if they consider further transactions with backers.

\subsubsection{Crowdfunding as a commitment tool}

Regarding the role of reputation, Chang (2020) discusses crowdfunding calls as a "commitment tool." Assuming rationality of backers and founders, crowdfunding only "works" if the founder has incentives to "build the project" after funds have been raised, rather than to "take the money and run." Thus, the funds raised by crowdfunding (the fixed costs in Chang's (2020) model) plus any expected profits from the crowdfunding project cannot exceed the value of the reputation that the founder is set to lose because of any misdemeanor. Under incomplete information, this calculation will hardly be precise for individual stakeholders. Nevertheless, this points out a severe restriction of crowdfunding, especially for creators without a strong reputation.

Overall, asymmetric information problems are rife with crowdfunding. However, to assess the potential for crowdfunding in CCI, this point should not be exaggerated (Dalla Chiesa \& Handke, 2020). Cultural products virtually always have pronounced experience good attributes, in any mode of interaction between suppliers and users. Users virtually always make decisions to engage with and buy into cultural products with incomplete information. The adequate reference point to evaluate crowdfunding is not an imaginary market with perfectly informed users, but crowdfunding's efficiency relative to other ways of organizing transactions in markets for cultural works.

\subsection{Public good attributes: ransom, personalized pricing, and assurance problems}

Many cultural products have pronounced public good attributes: important aspects of cultural products tend to be non-rival in consumption and non-excludable (Ginsburgh \& Throsby, 2006; Towse, 1997). There is relatively great potential for CCI to give rise to positive externalities, where benefits of creative production and creative works accrue to parties, who do not contribute to the revenues of suppliers. This may result in market failure, where aggregate investment and the supply of quasipublic works will probably fall well below its socially desirable level.

The copyright system is a costly means to mitigate market failure due to public good attributes (Handke, 2018; Towse et al., 2008). Digitalization has put the efficiency of current copyright regimes into question (Handke, 2010). How to develop 
an adequate copyright system remains highly contentious. Crowdfunding can be another means to mitigate problems due to the public good attributes of creative works (Hudik \& Chovanculiak, 2018), which may help circumvent some of the contentious issues associated with copyright policy (Dalla Chiesa \& Handke, 2020).

\subsubsection{Crowdfunding as ransom}

At the crowdfunding stage, a work is perfectly excludable, in the sense that the potential creator can simply choose not to produce. In an AON setup, the creator has less asset specificity than after the costs of creation are sunk. As founders, creators retain the option to withhold production, unless the call raises sufficient up-front revenue. Rational users may then be converted from free-riders to backers, who commit funds in order to increase the probability that a call reaches its goals and thus that the project commences and any finished goods become available at all (or sooner or with greater quality than without crowdfunding). Just before the term crowdfunding gained popularity, Varian (2005) thus described requests for up-front finance from potential users as "ransom."

\subsubsection{Personalized pricing}

In this context, it is important that crowdfunding calls usually give backers ample scope to determine the amounts they pledge (Gneezy et al., 2010; Hardy, 2013). This is akin to personalized pricing (first-order price discrimination), albeit with assurance problems and incentives for free-riding, as discussed below. Backers do not face a binary choice between purchasing at a single price, as buyers do without personalized pricing. Backers are enticed to reveal information about their WTP in excess of any minimum threshold set in the call. Among all potential beneficiaries, the project still has attributes of a public good. (Compared to auctions of rival and excludable goods - such as paintings sold for private use-the call only provides weak incentives for users to reveal their full willingness to pay.) Then a central question is, how much backers will pledge. ${ }^{14}$

An extensive literature on the private provision of public goods addresses this type of question, harnessing game theory (e.g., Andreoni, 1990; Cowen, 1992). For AON crowdfunding, the adequate model features a discontinuity of zero supply unless a minimum threshold of funding is raised, at which the founder expects to amortize fixed costs (cf. Hudik \& Chovanculiak, 2018).

The literature yields unspecific results. (Technically speaking, there are no unique Nash equilibria for many constellations, in which a call to jointly fund a good with public good attributes raises sufficient funding to cover fixed costs.) If there are any fixed costs for supplying the good in question, and no individual stakeholder

\footnotetext{
14 A special case is goods with some public benefits (at least among a set of stakeholders) and some excludable and private benefits. In essence, this just means that rational, potential users have a WTP corresponding to their private benefits, whereas public benefits are incompletely reflected in WTP, or not at all.
} 
is willing to cover the entire fixed costs by herself, there will either be no supply at all, or investments in production will fall below the social optimum (Hudik \& Chovanculiak, 2018). With differentiated products, this means that some works, which would generate greater social benefits than costs, are not produced.

However, if backers are sufficiently differentiated in terms of their WTP (or willingness to contribute), calls may raise substantially more revenues when they allow for backers to determine the amounts pledged themselves. Furthermore, product differentiation through diverse rewarding schemes and bundling may also enable founders to appropriate more of the surplus (see Sect. 4.8). In either case, market failure due to public good attributes will be mitigated.

\subsubsection{Assurance problems, AON setups, and reward-based crowdfunding}

Most benefits to backers can only come about if a campaign succeeds. Uncertainty about the success of the call, and thus about whether any benefits of the project or finished goods will transpire, entails an "assurance problem" (Runge, 1984). Backers risk losing out if they incur any costs in supporting a call that does not have sufficient appeal to other backers and thus does not come to fruition. Without the assurance that other backers also chip in with sufficient pledges, individual backers' propensity to pledge funds may be low (Kuppuswamy \& Bayus, 2018). The assurance problem helps to explain why AON setups are popular, which specify a funding target and reimburse backers if the campaign fails to reach this target.

The point is best illustrated with a simple, formal analysis. Let's assume that a founder $j$ sets up a crowdfunding call for a project which entails some costs of creation $f_{c}$ greater zero. Developing and presenting the call itself entails some fixed costs for the founder - the transaction costs of using the crowdfunding market-of $t_{j}$ greater zero. The total costs of the crowdfunding project incurred by the founder, before releasing any finished goods to market, are

$$
c_{j}=\left\{\begin{array}{l}
f_{c}+t_{j} \text { if the campaign succeeds } \\
t_{j} \text { if the campaign fails }
\end{array} .\right.
$$

If the crowdfunding campaign succeeds, the founder's revenue is $r=\sum_{i}^{n} p_{i}-p_{s}$, where $p_{i}$ denominates the amounts pledged by a representative backer, $i$, and $p_{s}$ denominates the price charged by the crowdfunding site if the call succeeds. (It is common practice of crowdfunding sites to only charge backers of successful calls.) If the campaign fails, the founder's revenue is zero.

Let's assume that the founder sets the funding target to its breakeven price, $r^{*}$. To specify this, we must consider the probability that the campaign will succeed, $P\left(r=r^{*}\right) \in[0, \ldots, 1]$, and with $P\left(r=r^{*}\right)$ strictly decreasing in $r^{*}$, so that

$$
r^{*}=f_{c}+p_{s}+\frac{t_{j}}{P\left(r=r^{*}\right)} .
$$


Let $u_{i}$ denominate a potential backer's expected utility if the campaign reaches its funding target (succeeds) and the project commences. If the call fails, $u_{i}=0$. (We assume that there is a definite fixed cost, and that the project cannot go ahead with reduced quality if fixed costs are not incurred in full.) Without reimbursement, the backer's costs are $p_{i}+t_{i}$, with $t_{i}$ denominating the backers' (transaction) costs of engaging with the call and making a pledge, regardless of whether the call succeeds or not. With reimbursement and ignoring discount rates over the time of the call and project, the backer's costs are

$$
c_{i}=\left\{\begin{array}{l}
p_{i}+t_{i} \text { if the campaign succeeds } \\
t_{i} \text { if the campaign fails }
\end{array} .\right.
$$

The campaign may succeed without any contribution by the backer if other backers pledge sufficient funding. Thus, pledging by rational backers hinges on the expected effect of their pledge on the probability that the campaign will succeed. There is indeed empirical evidence that potential backers are more likely to pledge if they expect their pledge increases the probability that the project commences, and any finished goods will become available (Kuppuswamy \& Bayus, 2017; Zvilichovsky et al., 2015). Without the specific backer's pledge the probability of success is $P\left(r=r^{*}\right)$, and this perceived probability changes as pledges by others are made and reported on the site. With the specific backer's pledge this probability is $P\left(r=r^{*}-p_{i}\right)$, and $P\left(r=r^{*}-p_{i}\right)-P\left(r=r^{*}\right)>0$.

Without reimbursement, a rational backer will make a pledge if $u_{i}\left(P\left(r=r^{*}-p_{i}\right)-P\left(r=r^{*}\right)\right)-\frac{p_{i}+t_{i}}{P\left(r=r^{*}-p_{i}\right)}>0$. With reimbursement, a rational backer will make a pledge if $u_{i}\left(P\left(r=r^{*}-p_{i}\right)-P\left(r=r^{*}\right)\right)-p_{i}-\frac{t_{i}}{P\left(r=r^{*}-p_{i}\right)}>0$. Thus, for calls with a low probability of success, the risk-adjusted price for backers may thus be several times higher than the nominal amounts pledged (since $P\left(r=r^{*}-p_{i}\right)<1$ ). This can trigger a vicious cycle, as fewer or lower pledges by other backers aggravates the assurance problem.

What is more, unless backers receive exclusive perks that are not available to conventional buyers at the retail stage, pledges will be low, as they are moderated by the effect of the individual backer's pledge (one of many in crowdfunding by definition) on the probability that the project will commence. In any case, a rational backer will set $p_{i}$ to maximize her net utility. We do not specify utility maximizing amounts pledged, $p_{i}$. In practice, this will be subject to great uncertainty about the probabilities of the call's success and the effect of the backer's pledge. As discussed in Sect. 4.8, the utility of backers may be determined by several benefits associated with the project or finished goods envisaged in the call. Social interdependence in demand formation further complicates the matter, for instance when the timing of a specific backers' pledge affects the probability and amounts pledged by other backers, who take their decision afterward. Furthermore, rational backers must consider 
the probability that the project commences funded in other ways, perhaps in an altered manner. Nevertheless, this basic analysis lets us clarify a number of issues.

AON setups. The assurance problem implies that backers' valuation of a crowdfunding call hinges not only on their appreciation of the project or any finished goods itself, but also on the call's appeal to other backers. Reimbursement in an AON setup has a direct effect on each individual backer: it reduces her costs from $p_{i}+t_{i}$ to $t_{i}$. Reimbursement also has an indirect effect on each backer, as reimbursement increases the probability that the campaign will reach its funding target, and thus the risk-adjusted utility associated with the call. Holding other things equal, the latter effect means that the assurance problem is lower and individual backers' WTP will increase. As reimbursement has these two effects, it may have rather pronounced overall effects on the probability that a campaign will succeed, which provides a rationalization, why AON setups are much more popular than KIA setups in crowdfunding of cultural products. ${ }^{15}$

Exclusive rewards to backers. Our analysis implies that backers pledge in order to increase the probability that the campaign will succeed. If this probability is high at the outset, there may be little scope for an additional pledge to increase the success probability. Then free-riding incentives may dominate. Specific rewards to backers can overcome this problem if they are not available for purchasing (or only available at a higher price) at the retail stage. The risk-adjusted value of rewards will increase in the success probability of the campaign. Besides, with low marginal costs in the provision of existing cultural products to additional customers, the direct costs of such rewards will be low. ${ }^{16}$ Thus, we have an explanation why reward-based crowdfunding combined with an AON setup is so popular, especially for cultural projects.

Appropriate funding targets. Another issue is how founders choose funding targets (see Hudik \& Chovanculiak, 2018). In much of the literature, the assumption is that founders set targets equal to the fixed costs of the project. Our analysis implies that they must set higher funding targets to break even, subject to the price charged by the platform, the fixed costs of the call, and the success probabilities of campaigns. Furthermore, founders may also consider higher funding targets to generate profits. Founders face several restrictions, however.

First, founders must trade off any profits to be had if they succeed with a high funding target against a higher probability to incur the fixed costs of a call $\left(t_{j}\right.$ in our model) with no revenues in case the campaign fails. According to our discussion of the assurance problem, the success probability of campaigns should, as a rule, decrease rapidly in the funding target.

Second, suppliers of cultural products operate in monopolistically competitive markets. On the one hand, the quality-adjusted funding targets (the aggregate price of a project) must also appear competitive relative to other calls. It has often been

\footnotetext{
15 This analysis is consistent with Bagnoli and Lippman (1989), and Tabarrok (1998), who discuss refunds (and rebates) as a means to overcome assurance problems in projects that seek to supply public goods.

${ }^{16}$ Sales displacement among backers, who would have also purchased at the retail price, may be substantial, however.
} 
argued that crowdfunding lowers barriers to entry, so that competition for crowdfunding may be fierce. On the other hand, many finished cultural products, which are close substitutes to goods envisaged in the call, will be available and entail less uncertainty for users. Exclusive rewards to backers, which are not available at the retail stage, may ensure that crowdfunding calls are still attractive.

Another restriction on setting high funding targets are the opportunity costs of failing with a campaign, beyond the costs of running a call, $t_{j}$. If a campaign succeeds and a project can be completed, there may be scope for incurring profits at the retailing stage. As argued above, the performance of founders' crowdfunding calls may also provide signals of quality to other investors or customers and increase the founders' prospects with future projects. Typically, creators must gradually build up their reputation over many creative projects to make any substantial profits (or even attain the status of a superstar). Overall, most creators, who set up crowdfunding calls, should thus rarely set funding targets that far exceed their costs of creation and of operating the call. ${ }^{17}$

It may be harder to explain, why it is common practice to close campaigns, once the funding target has been reached. Hudik and Chovanculiak (2018) refer back to the concept of overfunding in general literature on the private provision of public goods. In essence, backers may be more willing to contribute to the costs of producing a good with public good attributes, if other backers as well as the founder also demonstrate socially beneficial behavior. One way of demonstrating social mindedness for founders is setting modest funding targets (just enough to ensure production) and indeed closing campaigns once these targets have been reached.

Our analysis entails a more specific restriction due to crowdfunding's function as a commitment tool (Chang, 2020; see Sect. 4.4). If a campaign raises much funding, there is greater potential for moral hazard of the founder. Without a predetermined cutoff for the funds raised, this may undermine the appeal of the call at the outset. Early backers may fear that later backers (with incomplete information) provide excessive additional funding, which triggers moral hazard and undermines the benefits of the project for earlier backers, too.

\subsection{Socially interdependent demand formation: the ambiguity of quality signals in crowdfunding campaigns}

Cultural economists are well aware that the valuation of cultural products comes about in complex social processes. Quality uncertainty among users in markets for cultural products brings about socially interdependent demand formation (cf. Bikhchandani et al., 1992; Blaug, 2001; Cameron, 1995; Potts et al., 2008; Throsby,

\footnotetext{
17 The fixed costs of calls also entail incentives for founders to restrict the number of calls they simultaneously issue, even though this could allow them to pool risks. Calls by the same founder(s) are probably close substitutes for each other, so that several simultaneous calls-or calls in quick successioncould cannibalize each other. What is more, backers might worry that a founder is not fully committed to a crowdfunded project if the same founder issues additional calls before a current project has run its course.
} 
2003). Incompletely informed users may not rely on their private quality signal or the potentially biased information from suppliers. They may also seek out relevant information (signals of quality) from other, imperfectly informed, market participants, or from certifiers such as critics. Thus, interdependent decision making can explain fads and fashions as well as superstar effects. ${ }^{18}$

Extending on the analyses in Sect. 4.5, we can describe socially interdependent processes determining the success of crowdfunding calls. The willingness to contribute to the financing of cultural production does not only hinge on the expected utility of the cultural products. It is moderated by free-riding incentives, and, where up-front investments in production are concerned, assurance problems.

\subsubsection{Quality signals from prior pledges and herding}

Figure 2A depicts some initial components regarding the formation of expected utility. Potential backers can inspect the call itself to gather information on their expected utility of the call succeeding. They may also have other information on the reputation of the creator(s) involved. Furthermore, as a crowdfunding campaign proceeds, any pledging by others generates third-party information related to quality of the call itself, which becomes available to subsequent potential backers. Crowdfunding calls usually display the number of pledges and the total amount pledged so far. Over the course of the call, potential backers can thus observe the behavior of other users, and infer on their utility associated with the call. ${ }^{19}$ At the outset of a call, before many potential backers have made their decision, there are few signals of quality available from other backers. Personal acquaintances are particularly likely to pledge shortly after a campaign has started, and early backers may hope that their pledge will trigger other pledges (Agrawal et al., 2011). Once substantial pledges have been made, there are positive signals of quality, which should entice further pledging.

\subsubsection{Prior pledges and free-riding incentives}

However, due to free-riding incentives, there is a countervailing effect of initial pledges on rational backers' willingness to contribute themselves (Belleflamme et al., 2015). See the extended Fig. 2B for an illustration, where the gray arrow depicts an inverse effect.

Prior pledges increase the probability that the call will reach its funding target and commence, regardless of a subsequent backer's pledge. The closer a campaign is to reaching its funding target, the lower will be the effect of subsequent pledges on the probability that the call will succeed, and other potential backers can free-ride

\footnotetext{
18 Fads and fashions are wild swings in demand for specific cultural products. Superstar effects are extremely inequitable market outcomes that seem weakly related to intrinsic product qualities (Adler, 2006; Rosen, 1981).

19 Regarding donation-based crowdfunding, Smith et al. (2013) also discuss three peer effects: "competition to be the top donor," "desire to avoid being the bottom donor," and emulating the amounts donated by others.
} 
(A) Quality signals, prior pledges and herding



(B) Prior pledges and free-riding incentives

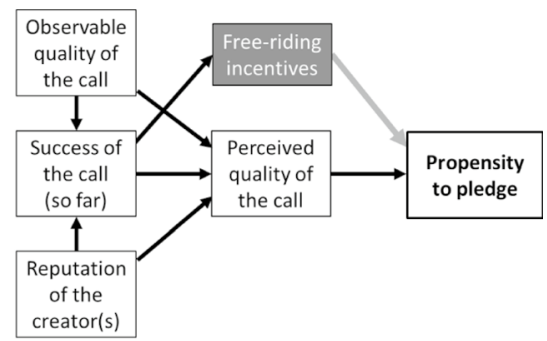

(C) Reputation, outside options and assurance problems

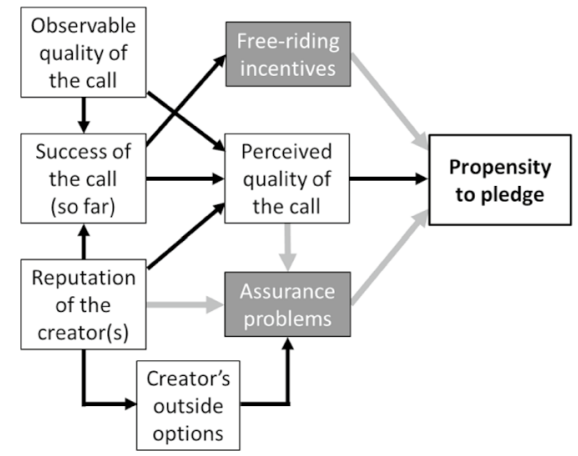

Fig. 2 a to $\mathbf{c}$ Various factors co-determining backers' propensity to pledge funds for a crowdfunding call. Notes Black arrows mark positive associations; grey arrows mark inverse associations. Free-riding incentives may also aggravate assurance problems

on funding pledged by others, hoping to enjoy any non-excludable benefits of the project or finished good without making substantial pledges themselves. Hobbs et al. (2016) refer to this phenomenon as "bystander effect", while Kuppuswamy and Bayus (2013) use the expression "gradient effect" for a similar phenomenon.

The relative importance of quality signaling effects and the countervailing freeriding effects is an empirical question (Belleflamme et al., 2015). For instance, according to Kuppuswamy and Bayus' (2017) study on calls posted on Kickstarter, free-riding effects dominate. By contrast, Agrawal et al. (2011) and Agrawal et al. (2015) find that "herding effects" due to signals from prior backers predominate. Recommendation systems on crowdfunding platforms could also foster herding, if they list calls in more prominent positions (make them easier to find) subject to the pledges already received. In any case, according to Agrawal et al. (2011), toward the end of a call period, backing tends to pick up again, especially if the call is close to reaching its funding target. This specific pattern may indicate that many backers, who have a high valuation of a call, seek to establish their chances of free-riding, before they commit. 


\subsubsection{Reputation, outside options, and assurance problems}

Assurance problems also moderate the propensity to pledge, as depicted by the extensions in Fig. 2C. Holding other things equal, founders with a strong track record and reputation are more likely to be able to generate high quality, and more likely to succeed, mitigating assurance problems among backers. Well-reputed founders are also more trustworthy, as they have more to lose from disappointing backers (see Sect. 4.4). However, "strong" founders also have better outside options: they have a higher probability of raising funds by other means than crowdfunding calls. Thus, rational backers may be more reluctant to pledge funding because there is less credible assurance that their pledge actually affects the probability that any prospective goods in question will become available. The expectation could be that production will commence anyway, regardless of the crowdfunding call.

\subsection{Intrinsic motivation to create}

There is extensive empirical evidence of intrinsic motivation to engage with cultural production (Throsby, 1994, 2001; Towse, 1997; Caves, 2000; Frey, 2003). Many creators seem willing to invest time and money - and to generate value for otherswithout a competitive pecuniary return. ${ }^{20}$ However, creative products entail fixed costs of creation. Even the most intrinsically motivated creator must raise sufficient funding to cover these costs, and private means of the creator do not always suffice. If it is to solve this problem, crowdfunding inevitably has a monetary component.

There may be a dilemma here. In crowdfunding calls, free-riding incentives of backers will as a rule be high. Crowdfunding will work much better if backers can be motivated to ignore free-riding incentives (see Sect. 4.8). Crowding theory suggests that selfless contributions are very sensitive to perceptions of selfish behavior by other stakeholders (Bürger \& Kleinert, 2020). This may be another reason, why success probabilities of campaigns may quickly deteriorate if founders display apparent profit-seeking behavior.

Furthermore, intrinsic motivation to engage in cultural production is not necessarily restricted to specialized creators. Indeed, some crowdfunding calls regarding cultural products offer participation in creative processes as a reward to backers (Brem et al., 2019; see Sect. 4.8). However, an issue closely related to intrinsic motivation is creators' apparent valuation of autonomy: they tend to value exclusive or extensive decision rights over the process of creation and the attributes of finished goods (Caves, 2000). There are probably trade-offs between creators' autonomy and "participation rewards."

\subsection{Backers' incentives: catering for diverse motives to support creativity}

Cultural economists have long discussed, why cultural products are appreciated and what motivates voluntary contributions to creative projects (Seaman, 1981; 2006;

\footnotetext{
${ }^{20}$ Alternative explanations of creators' below average earnings are risk-seeking (Benhamou, 2003; Rosen, 1981) or systematically biased, optimistic expectations (Towse, 2001).
} 


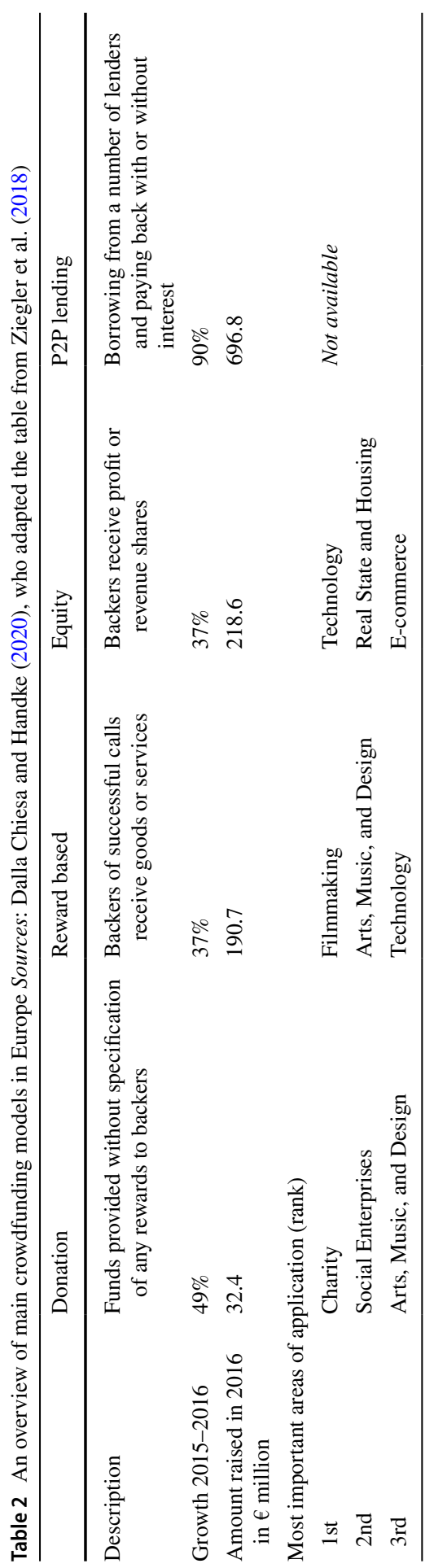


Frey, 1997). Research on the crowdfunding phenomenon has become an important arena for studying these types of questions in the cultural industries and in other aspects of the economy. One peculiar aspect of crowdfunding compared to other means of financing production (such as credit or retailing of finished goods) is that crowdfunding has been used to simultaneously cater for a relatively broad range of different incentives of backers/investors. A literature review by Moritz and Block (2016) already covered over 50 academic articles on "capital providers" (backers) and their motives in crowdfunding, published between 2006 and 2014, and since then this specific line of research has quickly expanded (e.g., Butticè \& Unghetto, 2021; Shneor \& Vik, 2020).

According to the types of backer incentives offered, Ziegler et al. (2018) distinguish donation crowdfunding, reward-based crowdfunding, and "crowdfunding as investment" (with two sub-types: equity and P2P lending). Economic studies often focus on one of these crowdfunding types only, and reward-based crowdfunding has received much attention (e.g., Belleflamme et al., 2018; Chang, 2020; Simpson, 2020). We also structure our overview into these categories, even though some incentives are difficult to place.

Table 2 gives an overview of growth and volumes of the types of crowdfunding, as well as of the most important areas of application. Reward-based models are relatively popular for cultural projects. Non-pecuniary rewards to backers vary widely. They can be a type of pre-selling, where backers receive final goods without further payment or at a rebate. Backers' rewards can also be intangible or tangible perks that are not marketed otherwise (Belleflamme et al., 2014; Crosetto \& Regner, 2014; Gamble, 2019).

However, another peculiar aspect of crowdfunding is that individual calls often combine various incentives to backers across these three types of crowdfunding models. Arguably, it is important to appreciate the flexibility of crowdfunding calls in combining (bundling) various goods and non-tradable incentives to potential backers with divergent interests.

\subsubsection{Reward-based crowdfunding}

Reward-based crowdfunding offers specific, non-pecuniary rewards to backers. Rewards feature in relatively many crowdfunding calls regarding cultural products, and the rewards offered are quite diverse.

Potential backers may appreciate cultural products for their own use. The corresponding incentive provided to backers in crowdfunding calls is the promise that due to a crowdfunding call, a specific cultural product will become available to the backer with a higher probability, earlier or in higher quality than without a successful crowdfunding campaign. For use value to materialize, users must enjoy access to the work in question. For cultural products that are non-rival in consumption and that entail very low marginal costs-say reproducible cultural products that can be delivered online-providing access entails few costs. For other cultural products, access as a reward entails greater full economic costs to founders. We thus expect that free access to finished goods should be more restricted for 
crowdfunding projects in the performing or fine arts than for reproducible cultural products.

As discussed in Sect. 4.5, the WTP for access to the same finished good will typically be lower at the crowdfunding stage than at the retailing stage. Among rational backers, pre-selling in a narrow sense requires backers to have a very high WTP relative to the eventual retail price; it will mostly appeal to proper fans, who may also have other incentives. Incentives to free-ride on the investments of others can be reduced if a call also promises that backers will enjoy exclusive perks, which will not be available to backers making more modest contributions, or to conventional buyers at the retail stage. For instance, backers may be offered special editions or personal meetings with the creators. ${ }^{21}$ This need for exclusivity applies to all other types of rewards discussed in this section.

Furthermore, engagement with culture may be a tool for social distinction. For this to work, the engagement of the distinguished stakeholder must be observable to others. $^{22}$ The corresponding incentive provided to backers is public acknowledgement of their engagement, say through attribution or exclusive memorabilia. ${ }^{23}$ In this manner, founders generate a private good to backers, which can help motivate stakeholders to finance public goods (Becker, 1974). Belleflamme et al. (2019), for instance, focus on "community benefits" for backers in crowdfunding, where backers' involvement in crowdfunding provides "consumers with an increase in the product quality" because they "essentially value the feeling of belonging to a group of 'special' or 'privileged' consumers. It is therefore important for the entrepreneur to attract a sufficient number of regular (i.e., 'non-privileged') consumers to whom crowdfunders [backers] can feel somehow 'superior'."

Finally, as we discuss in Sect. 4.7, participation in creative processes is often appreciated in its own right. Intrinsic motivation to create may extend to backers. The corresponding rewards provided to backers may be an opportunity to contribute, say as an extra in a movie or by jointly performing with the founder on stage in a musical performance.

\subsubsection{Crowdfunding as a commercial investment}

Like conventional funding methods of commercial enterprises, some crowdfunding calls offer a future financial return on backers' initial investment at the crowdfunding stage (see Agrawal et al., 2014). Stakeholders may appreciate rights in a cultural project or product as an investment: an asset that stores pecuniary value and yields competitive returns in the future.

\footnotetext{
21 There may be moral hazard, however, for the founder to keep the promise of exclusivity after crowdfunding success.

22 Transparency of backers' actions may also trigger "peer effects" and foster pledging (Smith et al., 2013).

23 Sometimes, even expressions of gratitude by the founder, or just the "warm glow" from having done the founder a favor may provide some incentive for backers. Where no specific action by the founder is required for an incentive to transpire, we speak of donation crowdfunding.
} 
Ziegler et al. (2018) distinguish two sub-types. In P2P lending, the founder commits to a credit contract, where the founder is liable to make future payments to the backer irrespective of any subsequent success metrics. In equity-based crowdfunding, future payments from the founder to the backer are subject to success metrics.

P2P-lending and equity-based crowdfunding accounts for the bulk of all funds raised via this type of financing (see Table 2). This is in spite of pronounced challenges due to asymmetric information. In contrast to professional investors and providers of credit, crowdfunding reaches out to private individuals. Many backers have limited expertise and may be vulnerable to strategies of founders, which exploit asymmetric information (see Sect. 4.4). Such concerns seem to be behind regulation of crowdfunding (Agrawal et al., 2015; Lazzaro \& Noonan, 2020; Stemler, 2013). What is more, if founders/creators appreciate autonomy, they may find it disagreeable to depend on a single, main investor, who could seek to excerpt an influence on what happens with "her money." Furthermore, pecuniary incentives may be an ill-fit with other crowdfunding incentives provided to backers. In any case, P2P-lending or equity-based crowdfunding (with or without decision rights) is quite rare in crowdfunding of cultural projects.

\subsubsection{Donation-based crowdfunding}

Donation-based crowdfunding specifies no quid pro quo for backers. Without any financial return nor pre-selling of specific goods or services, rational backers' incentives hinge on their expectations regarding indirect use value (Andersson et al., 2012) or non-use value (Frey, 2003; Hansen, 1997; Martin, 1994) associated with cultural production and with supporting it. ${ }^{24}$

As discussed in Sect. 4.5, cultural products often have pronounced public good attributes, and generate positive externalities. Backers may value the corresponding indirect benefits they expect to enjoy, for instance because others make use of a cultural product. Backers may even be properly altruistic. They may value creators' well-being in its own right. Backers may also value the availability of cultural products to others, irrespective of whether backers expect any direct or indirect benefits to themselves. ${ }^{25}$ Various types of non-use value are hard to distinguish in practice, however.

We have discussed specific services or goods, which enable recognition and social distinction of backers under "reward-based crowdfunding." Even without explicit acknowledgement, backers may sometimes derive "psychic benefits" (Csikszentmihalyi, 2000; Frey \& Eichenberger, 1995) from demonstrating just to themselves

\footnotetext{
${ }^{24}$ Categorizations of sources of values not reflected in conventional markets vary between authors. According to Plottu and Plottu (2007), indirect use value concerns the utility of non-excludable and nonexhaustible aspects of products or assets, which accrue to users. Non-use value accrues independently of any use/consumption of a good or service by the stakeholder in question (backers in our case), and many cultural economists distinguish between option value, bequest value, and existence value (Martin, 1994; Frey, 2003; Anderson et al., 2012). The exact boundaries between these values remain contested and distinguishing them in applied empirical work can be tricky (Hansen, 1997).

25 Interestingly, one way to document this for founders could indeed be to also provide easy access to backers, which documents again that it is hard to separate various incentives for backers from each other, or to identify singular incentives provided by rewards.
} 
that they support a project regardless of any recognition from other parties. Choy and Schlagwein (2016) speak of "socially intrinsic motivation," Cecere et al. (2017) refer to similar phenomena as "warm glow" based on Andreoni's (1990) extensive work. Cox et al. (2018) and Zhang and Chen (2019) prefer the expression (self-) satisfaction. Again, it may be hard to distinguish this phenomenon from virtue signaling to others or from trying to ingratiate the founder, which could generate more specific benefits in the future.

\subsubsection{Combining various backer incentives}

Founders often use crowdfunding to diversify the goods and services they supply and to offer goods that are not tradable in a conventional manner. What is more, crowdfunding enables bundling of various goods and services, to extract greater surplus from users (McAfee et al. 1998). This raises the question: how best to combine incentives offered to backers (cf. Shi, 2018)?

Here, crowding theory (DiGaetano \& Mazza, 2017; Frey \& Jegen, 2001) as a staple of cultural economics is useful. ${ }^{26}$ For instance, if crowdfunding invokes commercial incentives on both sides-also among investors/backers-crowding-out of other incentives from rewards or in particular from selfless contributions may occur (Boeuf et al., 2014; Cecere et al., 2017; Dalla Chiesa \& Dekker, 2021). What is more, founders must strike a precarious balance between motivating selfless contributions or a community spirit, and the inevitable pecuniary aspect of crowdfunding as a means to provide sufficient capital to commence with the project. By definition, crowdfunding entails financial transactions, not merely expressions of interest via a "like" or positive vote. Potential backers may have good intuitions that it is essential for founders to cover fixed costs. However, backers may feel reluctant to override free-riding incentives, assurance problems, and asymmetric information problems if founders do not acknowledge their own "psychic benefits" or signal some altruism themselves. A backlash against the use of crowdfunding by some famous, presumably wealthy, creators relate to this point, see Watercutter (2013). To succeed with a campaign, founders may have to demonstrate need and generosity, and compromise profit-making opportunities.

If due to crowding-out, crowdfunding is relatively limited as a means for founders to generate profits, crowdfunding will have limited appeal to producers of creative works. Over the course of their career, creators will probably seek to also use other sources of raising up-front capital, especially regarding projects deemed to have great commercial potential. ${ }^{27}$ Then crowdfunding is clearly not a perfect substitute

\footnotetext{
${ }^{26}$ Klamer (2016) discusses various values associated with cultural activities and individuals or organizations engaging with it, which could be employed to expand the discussion of crowdfunding. The connection to standard welfare economics as employed in this paper remains tenuous. Other promising extensions to the cultural economics repertoire derive from behavioral economics - see Coate and Hoffmann (2021) — as "psychological 'anomalies"” seem rife in the behavior of stakeholders in the cultural sector. For reasons of space, we do not develop these arguments here.

27 See Walthoff-Borm et al. (2018) regarding equity crowdfunding as a "last resort" among a range of financing options.
} 
for traded means of raising capital. For instance, deals between creators and traditional intermediaries in CCI (such as record companies or film production companies, who raise up-front capital as one of their main functions) will still have some appeal, even though the bargaining position of some creators will be fostered after initial crowdfunding success or due to the potential for crowdfunding for dis- or reintermediation (cf. Harrison, 2013). Much empirical work remains on complementarities and substitution between crowdfunding and alternative means of financing cultural production.

\section{Discussion}

We set out to address three fundamental questions regarding crowdfunding in CCI, which require further attention. Based on our collage of the crowdfunding literature and hallmarks of cultural economics, we can offer preliminary answers.

\subsection{Under what circumstances is crowdfunding a superior alternative to traded means of financing innovative projects?}

Crowdfunding is a means to raise up-front capital for cultural products. It helps overcome an essential problem in CCI: how to cover high up-front costs of creation, when any revenues from retailing of finished goods come with a delay and are uncertain? Compared to the more conventional mode of raising up-front capital through credit or sales of equity to commercial investors, crowdfunding overcomes the separation of investors and users. Crowdfunding is a means to convert potential buyers at a later retail stage (or free-riders) into investors, who make funding available to founders before the full costs of creation are incurred. In CCI crowdfunding, backers mostly pledge without a commercial interest but based on the use value or non-use value of the cultural project or cultural product envisaged in the call.

Obviously, crowdfunding is more likely to be a superior substitute for commercial financing of up-front production costs subject to any market failure in commercial finance-an issue that is beyond the scope of this paper. Furthermore, crowdfunding will be relatively efficient: (1) the more producers suffer from demand uncertainty and thus appreciate the possibility to test the market; (2) for suppliers of goods with strong experience good attributes, who can use crowdfunding to engage others, to reveal relevant information and alleviate quality uncertainty on the demand side. This reputation building and engagement may work best over a series of calls, however. Furthermore, crowdfunding may be a superior option, as it triggers socially interdependent valuation processes, in which backers emanate signals of quality. (3) Crowdfunding also allows for relatively refined price discrimination-including personalized pricing - and will thus be advantageous when stakeholders on the demand side are widely differentiated in terms of their WTP. (4) Crowdfunding may also be preferred by producers, who value autonomy in operating production processes and uncompromised control over the characteristics of finished goods. (5) Perhaps most importantly, crowdfunding may be superior to finance the production of goods with 
strong public good attributes, which commercial investors will not value. (6) Finally, cultural products are appreciated for various reasons. Crowdfunding allows producers to simultaneously offer, combine and bundle many different value propositions to investors, which may extend the market and increase surplus of appropriation by the producer.

Regarding the prevalence of these conditions in CCI, crowdfunding probably fills some sustainable niches.

\subsection{What types of crowdfunding are best suited for specific (cultural and creative) industries?}

Crowdfunding is a costly means to raise up-front capital. For instance, campaigns take time. Crowdfunding will be useful for those cultural projects, where the opportunity costs of time are low and the need for up-front capital is high. What is more, crowdfunding may have disadvantages for producers in intense monopolistic competition, who must fear that the information they issue with a call allows competitors to emulate the project in question. ${ }^{28}$

Some crowdfunding setups and types predominate in CCI crowdfunding. Our analysis provides some theoretical rationalization. On the one hand, AON setups with refunds are useful to reduce assurance problems and the risk-adjusted price for backers, which will be most useful where the probabilities of success are low. This may be particularly important for projects that are very costly and need to motivate numerous and/or high-value pledges (say films, complex video games, or large-scale performances, as opposed to a sound recording or literary work). Refunds may also be useful for creators, who do not as yet enjoy a strong reputation. On the other hand, pre-selling, as a special type of reward-based crowdfunding, is particularly suitable where marginal costs are low (say for reproducible cultural products that can be disseminated online). Pre-selling is also more suitable with non-rivalry in consumption, which may restrict pre-selling via crowdfunding for performing arts (cf. Boeuf et al., 2014) or fine arts, for instance.

Furthermore, crowdfunding is more promising, the greater the public goods attributes of the cultural good in question are. While crowdfunding does not do away with market failure due to non-excludability and free-rider incentives, it may mitigate them. Again, this seems to make crowdfunding more promising for reproducible cultural products than for relatively more excludable and rival cultural products (the arts).

Finally, social distinction seems to play a strong role in CCI crowdfunding. This may make crowdfunding more suitable for cultural products that bestow high prestige-say works of high arts or cultural expressions that are treasured aspect of cultural heritage in an influential community. Few specific cultural projects will tick all these boxes. This hints at considerable limitations of crowdfunding in CCI.

\footnotetext{
28 Crowdfunding entails a strategic decision of creators and innovators, how far (s)he will try and develop a creation before revealing it to others in order to sell it or attract investors. For a theoretical discussion regarding the example of scriptwriters, see Luo (2014).
} 


\subsection{What is the potential of crowdfunding for $\mathrm{CCl}$ ?}

CCI crowdfunding is a recent and rapidly expanding phenomenon. At present, however, crowdfunding raises only a tiny fraction of total revenues to CCI. Certain predictions are not feasible at this point, not least because crowdfunding is likely to improve over time, like most novel technologies. Nevertheless, our analysis entails several restrictions of crowdfunding.

First, asymmetric information problems and quality uncertainty are rife with crowdfunding because at the crowdfunding stage, no finished good is available for inspection. While such problems are also found at the retailing stage in CCI, they will tend to be more pronounced in crowdfunding.

Second, crowdfunding requires many transactions. Online platforms can reduce average transaction costs but cannot entirely do away with them. The remaining transaction costs may still restrict the provision of finance from many stakeholders; the WTP for specific cultural products is often low due to monopolistic competition (close substitutes being available). In the aggregate, the provision of finance from large investors (patrons, commercial investors, or the public sector), which require fewer transactions, may often be more efficient in terms of requiring lower average transaction costs per $\$$ raised.

Third, crowdfunding can work as ransom, when founders make a credible threat that they will not produce unless a campaign succeeds. This mitigates problems with private funding of quasi-public goods, such as many cultural products. However, so-called pre-selling of finished goods has limited application. That is because the propensity of pledging is moderated by the remaining free-rider incentives, the limited effect of an individual pledge on the probability that the call will succeed, and assurance problems. Pre-selling will only work if there is a number of users with extraordinarily high WTP, to overcome these moderating factors. In other words, crowdfunding is a way to reach out to dedicated fans, rather than more conventional customers.

Finally, regarding the types of creators, who may prefer crowdfunding, there is a bit of a dilemma. Whereas newcomers may not have the reputation to motivate backers, established (super)stars can hardly make credible threats that they will not produce without crowdfunding, as they have good outside options. The same logic may apply to specific calls: the better they are, in particular regarding their commercial potential, the less likely it is that backers need to pledge substantial amounts to make them happen.

\section{Conclusions}

Crowdfunding is an innovation from the cultural sector that has already had broad applications in many other aspects of the economy. We document that cultural economics provides a useful structure for explaining much of the crowdfunding phenomenon.

Based on main themes in cultural economics, this article discusses several benefits of crowdfunding, relative to other costly means of funding cultural production. 
For instance, at the crowdfunding stage, prospective cultural works are excludable, if ill-defined. Furthermore, crowdfunding is a means for product differentiation, which allows creators to simultaneously cater for a diverse set of incentives to engage with culture among donors and users. Given its relative benefits and wide application over recent years, it seems rather certain that crowdfunding is here to stay. On the other hand, crowdfunding is limited, due to asymmetric information, assurance problems, and free-rider incentives. Adoption of crowdfunding indicates severe market failure regarding other modes of financing culture. The predominant modes of crowdfunding in CCI can be rationalized as means to mitigate such issues. Nevertheless, as a rule, rational users will pledge only a fraction of their WTP, subject to their observations and expectations regarding the behavior of other (potential) backers. Pure preselling is unlikely to work well, and founders will usually need to appeal to non-use values or even altruism. At the heart of crowdfunding, we thus find the usual tension between art and commerce, where founders have better chances of attaining monetary contributions, if they appeal to social and cultural values.

There is considerable scope for future research. First, much theoretical and empirical work remains on mapping out, which crowdfunding setups are most suited for specific cultural industries or creative projects of different types (cf. Rykkja et al., 2020).

Second, it is a fascinating empirical question to what extent crowdfunding promotes allocative efficiency and diversity in the CCI, as it generates information and offers promising creators an additional source of funding. However, there is a dilemma at the heart of crowdfunding. Regarding newcomers and fringe creators, crowdfunding could lower barriers to entry and superstar effects in traded CCI, fostering competition and diversity. That only works, though, if founders somehow acquire the reputation needed to succeed with a campaign. The reputation problem familiar from other means of funding innovation persists (cf. Hall \& Lerner, 2010), even though the scope of potential funders is expanded. Much empirical work remains to establish whether crowdfunding can diminish superstar effects. Among established (super)star creators, the application of crowdfunding also seems limited. Stars can hardly threaten they will not produce without generous backing (hold stakeholders to "ransom") because they have strong outside options. Overall, we predict that crowdfunding will remain quite confined as a means to bring about a more equitable or efficient allocation of resources in CCI.

A third important issue for further research remains beyond the current paper: crowdfunding platforms probably operate in a similar way as other online platforms in two- or multi-sided markets. Due to direct and indirect network effects, there may be a tendency for monopolization and centralized control in this online service, too. So far, there are many crowdfunding platforms and there seem to be low barriers to entry. This may change as the market for crowdfunding platforms and relevant technologies mature, or due to regulation of this novel type of finance. That relates to a fourth area of further research on crowdfunding: the appropriate type of statutory regulation. Similar to developments of other online services, crowdfunding has first grown and expanded under relatively limited regulation. As crowdfunding expanded beyond more or less charitable giving into commercial investments in technology and real estate, more extensive regulation has been introduced. However, in the 
cultural sector, donation and reward-based crowdfunding remains preeminent. This is consistent with the notion that cultural products are mostly appreciated for their consumption value and their non-use value due to positive externalities that they entail, rather than for their value as a financial investment. The need for regulation may thus be rather different than for profit-oriented investments.

Finally, the major benefit of crowdfunding for cultural economics may not derive from any fostering of CCI but transpire on a different level: crowdfunding generates abundant data and changes restrictions for participants in the cultural sector, which entails opportunities to develop new empirical insights on cultural industries, over and beyond crowdfunding itself. The crowdfunding literature encompasses much and leading work on central themes in cultural economics, and the generic crowdfunding literature might advance more swiftly if it reliably drew on longstanding debates in cultural economics. In a sense, crowdfunding operates a plethora of contingent valuation studies and choice experiments. This is a gift for cultural economics that will keep on giving for a long time to come.

Acknowledgements Parts of this paper draw heavily on a brief chapter by the same authors, Dalla Chiesa and Handke (2020), in The Handbook of Cultural Economics (3rd edition), edited by Ruth Towse and Trilce Navarette and published by Edward Elgar. Christian Handke gratefully acknowledges funding from the Research Council Norway (Project Number 301502).

Open Access This article is licensed under a Creative Commons Attribution 4.0 International License, which permits use, sharing, adaptation, distribution and reproduction in any medium or format, as long as you give appropriate credit to the original author(s) and the source, provide a link to the Creative Commons licence, and indicate if changes were made. The images or other third party material in this article are included in the article's Creative Commons licence, unless indicated otherwise in a credit line to the material. If material is not included in the article's Creative Commons licence and your intended use is not permitted by statutory regulation or exceeds the permitted use, you will need to obtain permission directly from the copyright holder. To view a copy of this licence, visit http://creativecommons.org/licen ses/by/4.0/.

\section{References}

Adler, M. (2006). Stardom and talent. In Ginsburgh, V. A., \& Throsby, D. (Eds.), Handbook of the Economics of Art and Culture (Vol. 1). Elsevier, pp. 486-499.

Agrawal, A. K., Catalini, C., \& Goldfarb, A. (2011). The geography of crowdfunding. National Bureau of Economic Research, Working paper no. w16820. Available online: http://www.nber.org/papers/ w16820.pdf. Accessed 21 August 2020.

Agrawal, A. K., Catalini, C., \& Goldfarb, A. (2014). Some simple economics of crowdfunding. Innovation Policy and the Economy, 14(1), 63-97.

Agrawal, A. K., Catalini, C., \& Goldfarb, A. (2015). Crowdfunding: Geography, social networks, and the timing of investment decisions. Journal of Economics \& Management Strategy, 24(2), 253-274.

Allison, T. H., Davis, B. C., Short, J. C., \& Webb, J. W. (2015). Crowdfunding in a prosocial microlending environment: Examining the role of intrinsic versus extrinsic cues. Entrepreneurship Theory and Practice, 39(1), 53-73.

Allison, T. H., McKenny, A. F., \& Short, J. C. (2013). The effect of entrepreneurial rhetoric on microlending investment: An examination of the warm-glow effect. Journal of Business Venturing, 28(6), 690-707.

Andersson, T. D., Armbrecht, J., \& Lundberg, E. (2012). Estimating use and non-use values of a music festival. Scandinavian Journal of Hospitality and Tourism, 12(3), 215-231. 
Andreoni, J. (1990). Impure altruism and donations to public goods: Atheory of warm-glow giving? The Economic Journal, 100(401), 464-477.

Andreoni, J., \& Payne, A. A. (2003). Do government grants to private charities crowd out giving or fundraising? The American Economic Review, 93(3), 792-812.

Angelini, F., \& Castellani, M. (2019). Cultural and economic value: A critical review. Journal of Cultural Economics, 43(2), 173-188.

Armstrong, M. (2006). Competition in two-sided markets. The RAND Journal of Economics, 37(3), $668-691$.

Baeck, P., Bone, J. \& Mitchell, S. (2017). Matching the Crowd: Combining Crowdfunding and Institutional Funding to Get Great Ideas off the Ground. London: NESTA. Retrieved from: https:// www.nesta.org.uk/report/matching-the-crowd-combining-crowdfunding-and-institutional-fundi ng-to-get-great-ideas-off-the-ground/

Bagnoli, M., \& Lipman, B. (1989). Provision of Public Goods: Fully Implementing the Core through Private Contributions. Review of Economic Studies, 56(4), 583-601.

Barasinska, N., \& Schäfer, D. (2014). Is crowdfunding different? Evidence on the relation between gender and funding success from a german peer-to-peer lending platform. German Economic Review, 15(4), 436-452.

Barzilay, O. Geva, H. Goldstein, A., \& Oestreicher-Singer, G. (2018). Equal opportunity for all? The long tail of crowdfunding: Evidence from Kickstarter. Available on SSRN: https://ssrn.com/abstract= 3215280. Accessed 10 December 2020.

Becker, G. S. (1974). A theory of social interactions. Journal of Political Economy, 82(6), 1063-1093.

Belleflamme, P., Lambert, T., \& Schwienbacher, A. (2018). Network effects in crowdfunding. Available on SSRN: https://ssrn.com/3259191. Accessed 02 August 2020.

Belleflamme, P., Lambert, T., \& Schwienbacher, A. (2019). Crowdfunding dynamics, CESifo Working Paper, No. 7797, Center for Economic Studies and ifo Institute (CESifo), Munich. Available on SSRN: https://ssrn.com/abstract=3468029. Accessed 10 November 2020.

Belleflamme, P., Lambert, T., \& Schwienbacher, A. (2014). Crowdfunding: Tapping the right crowd. Journal of Business Venturing, 29(5), 585-609.

Belleflamme, P., Omrani, N., \& Peitz, M. (2015). The economics of crowdfunding platforms. Information Economics and Policy, 33, 11-28.

Benhamou, F. (2003). Artists' labour market. In R. Towse (Ed.), A handbook of cultural economics (3rd ed., pp. 53-58). Edward Elgar.

Bianchi, M. (2002). Novelty, preferences, and fashion: When goods are unsettling. Journal of Economic Behavior \& Organization, 47(1), 1-18.

Bidaux, T. (2020, January 15). Kickstarter and Games in 2019. Icopartners.Com. https://icopartners.com/ 2020/01/kickstarter-and-games-in-2019/

Bikhchandani, S., Hirshleifer, D., \& Welch, I. (1992). A theory of fads, fashion, custom, and cultural change as informational cascades. Journal of Political Economy, 100(5), 992-1026.

Blaug, M. (2001). Where are we now on cultural economics? Journal of Economic Surveys, 15(2), 123-143.

Boeuf, B., Darveau, J., \& Legoux, R. (2014). Financing creativity: Crowdfunding as a new approach for theatre projects. International Journal of Arts Management, 16(3), 33-48.

Borst, I., Moser, C., \& Ferguson, J. (2018). From friendfunding to crowdfunding: Relevance of relationships, social media, and platform activities to crowdfunding performance. New Media Society, 20(4), 1396-1414.

Bradley, D. B., III., \& Luong, C. (2014). Crowdfunding: A new opportunity for small business and entrepreneurship. The Entrepreneurial Executive, 19(2014), 95-104.

Brem, A., Bilgram, V., \& Marchuk, A. (2019). How crowdfunding platforms change the nature of user innovation - from problem solving to entrepreneurship. Technological Forecasting and Social Change, 144(July 2019), 348-360.

Bretschneider, U., \& Leimeister, J. M. (2017). Not just an ego-trip: Exploring backers' motivation for funding in incentive-based crowdfunding. The Journal of Strategic Information Systems, 26(4), 246-260.

Breznitz, S. M., \& Noonan, D. S. (2020) Crowdfunding in a not-so-flat world. Journal of Economic Geography, 20(4), 1069-1092. https://doi.org/10.1093/jeg/lbaa008.

Brown, T. E., Boon, E., \& Pitt, L. F. (2017). Seeking funding in order to sell: Crowdfunding as a marketing tool. Business Horizons, 60(2), 189-195. 
Brzozowska, B., \& Galuszka, P. (2021). Crowdfunding and independence in film and music (1st ed.). Routledge. https://doi.org/10.4324/9781003150787.

Bürger, T., \& Kleinert, S. (2020). Crowdfunding cultural and commercial entrepreneurs: An empirical study on motivation in distinct backer communities. Small Business Economics. https://doi.org/10. $1007 / \mathrm{s} 11187-020-00419-8$

Butticè, V., \& Ughetto, E. (2021). What, Where, Who, and How? A bibliometric study of crowdfunding research. IEEE Transactions on Engineering Management, 1-22.

Calic, G., \& Mosakowski, E. (2016). Kicking off social entrepreneurship: How a sustainability orientation influences crowdfunding success. Journal of Management Studies, 53(5), 738-767.

Cameron, S. (1995). On the role of critics in the culture industry. Journal of Cultural Economics, 19(4), $321-331$.

Cameron, S. (2016). Past, present and future: Music economics at the crossroads. Journal of Cultural Economics, 40(1), 1-12.

Caves, R. (2000). Creative industries: Contracts between art and commerce. Cambridge, MA: Harvard University Press.

Cecere, G., Le Guel, F., \& Rochelandet, F. (2017). Crowdfunding and social influence: An empirical investigation. Applied Economics, 49(57), 5802-5813.

Chan, C. R., \& Parhankangas, A. (2017). Crowdfunding innovative ideas: How incremental and radical innovativeness influence funding outcomes. Entrepreneurship Theory and Practice, 41(2), $237-263$.

Chang, J. (2020). The economics of crowdfunding. American Economic Journal: Microeconomics, 12(2), 257-280.

Cholakova, M., \& Clarysse, B. (2015). Does the possibility to make equity investments in crowdfunding projects crowd out reward-based investments? Entrepreneurship Theory and Practice, 39(1), $145-172$.

Choy, K., \& Schlagwein, D. (2016). Crowdsourcing for a better world: On the relation between IT affordances and donor motivations in charitable crowdfunding. Information Technology \& People, 29(1), 221-247.

Clauss, T., Breitenecker, R. J., Kraus, S., Brem, A., \& Richter, C. (2018). Directing the wisdom of the crowd: The importance of social interaction among founders and the crowd during crowdfunding campaigns. Economics of. Innovation and New Technology, 27(8), 709-729.

Coate, B., \& Hoffmann, R. (2021). The behavioural economics of culture. Journal of Cultural Economics. https://doi.org/10.1007/s10824-021-09419-2

Colombo, M. G., Franzoni, C., \& Rossi-Lamastra, C. (2015). Internal social capital and the attraction of early contributions in crowdfunding. Entrepreneurship: Theory \& Practice, 39(1), 75-100.

Colombo, O. (2021). The use of signals in new-venture financing: a review and research Agenda. Journal of Management, 47(1), 237-259.

Cowen, T. (1992). Law as a public good: The economics of anarchy. Economics and Philosophy, 8(2), 249-267.

Cox, J., Nguyen, T., \& Kang, S. M. (2018). The kindness of strangers? An investigation into the interaction of funder motivations in online crowdfunding campaigns. Kyklos, 71(2), 187-212.

Crosetto, P., \& Regner, P. (2014). Crowdfunding: Determinants of success and funding dynamics. Jena Economic Research Papers no. 2014-035, Friedrich-Schiller-University Jena.

Csikszentmihalyi, M. (2000). The costs and benefits of consuming. Journal of Consumer Research, 27(2), 267-272.

Cumming, D., \& Hornuf, L. (Eds.). (2018). The economics of crowdfunding. Palgrave Macmillan.

Dalla Chiesa, C., \& Dekker, E. (2021). Crowdfunding artists: Beyond match-making on platforms. SocioEconomic Review, 19(4), 1265-1290.

Dalla Chiesa, C., \& Handke, C. (2020). Crowdfunding. In R. Towse \& T. Navarette (Eds.), A handbook of cultural economics (3rd ed., pp. 158-167). Edward Elgar.

Davies, R. (2015). Three provocations for civic crowdfunding. Information, Communication \& Society, 18(3), 342-355.

Di Gaetano, L., \& Mazza, I. (2017). Better an egg today than a hen tomorrow on the implications of deaccess policies for donations to museums. Journal of Cultural Economics, 41(3), 237-258.

Doshi, A. (2014). Agent heterogeneity in two-sided platforms: superstar impact on crowdfunding. SSRN Electronic Journal. Retrieved from: https://conference.nber.org/confer/2014/SI2014/PRIT/Doshi. pdf 
Frey, B. S. (1997). Evaluating cultural property: The economic approach. International Journal of Cultural Property, 6(2), 231-246.

Frey, B. S. (2003). Arts and economics: Analysis and cultural policy. Springer.

Frey, B. S., \& Eichenberger, R. (1995). On the return of art investment return analysis. Journal of Cultural Economics, 19(3), 207-220.

Frey, B. S., \& Jegen, R. (2001). Motivation crowding theory. Journal of Economic Surveys, 15(5), 589-611.

Gafni, H., Marom, D., Robb, A., \& Sade, O. (2020). Gender dynamics in crowdfunding (Kickstarter): Evidence on entrepreneurs, backers, and taste-based discrimination. Review of Finance. https://doi. org/10.1093/rof/rfaa041

Gafni, H., Marom, D., \& Sade, O. (2019). Are the life and death of an early-stage venture indeed in the power of the tongue? Lessons from online crowdfunding pitches. Strategy Entrepreneurship Journal, 13(1), 3-23.

Galuszka, P., \& Brzozowska, B. (2017). Crowdfunding: Towards a redefinition of the artist's role - the case of MegaTotal. International Journal of Cultural Studies, 20(1), 83-99.

Gamble, J. R. (2019). Marketing madness or financial folly? Implementing equity crowdfunding in the record industry. European Journal of Marketing, 53(3), 412-441.

Ganatra, J.H. (2016). When a Kickstarter stops: Exploring failures and regulatory frameworks for the rewards-based crowdfunding industry. Rutgers University Law Review, 68(3).

Gerber, E. M., \& Hui, J. (2016), Crowdfunding: How and Why People participate. In: Méric, J., Maque, I., Brabet, J. (Ed.), International perspectives on crowdfunding: Positive, normative and critical theory, UK: Emerald Insight.

Ginsburgh, V., \& Throsby, C. D. (2006). Handbook on the economics of art and culture. Elsevier.

Gneezy, A., Gneezy, U., Nelson, L., \& Brown, A. (2010). Shared social responsibility: A field experiment in pay-what-you-want pricing and charitable giving. Science, 329(5989), new series, 325-327.

Gorbatai, A., \& Nelson, L. (2015). Gender and the language of crowdfunding. Academy of Management Proceedings, 2015, 15785-15785.

Gras, D., Robert, S. N., Lerman, M., \& Stellini, M. (2017). Going offline: Broadening crowdfunding research beyond the online context. Venture Capital, 19(3), 217-237.

Hall, B. H., \& Lerner, J. (2010). The financing of R\&D and innovation. In B. H. Hall \& N. Rosenberg (Eds.), Handbook of the economics of innovation (Vol. 1, pp. 609-635). Elsevier.

Handke, C. (2010). The Economics of Copyright and Digitalisation - A Report on the Literature and the Need for Further Research. Report for the Strategic Advisory Board for Intellectual Property Policy (SABIP), UK. Online: https://papers.ssrn.com/sol3/papers.cfm?abstract_id=2707153. Accessed 10 December 2020.

Handke, C. (2006). Plain destruction or creative destruction? Copyright erosion and the evolution of the record industry. Review of Economic Research on Copyright Issues, 3(2), 29-51.

Handke, C. (2012). Digital copying and the supply of sound recordings. Information Economics and Policy, 24(1), 15-29.

Handke, C. (2018). Intellectual property in creative industries: The economic perspective. In C. Waelde \& A. Brown (Eds.), Research handbook on intellectual property and creative industries (pp. 57-78). Edward Elgar.

Handke, C., Balazs, B., \& Vallbé, J. J. (2016). Going means trouble and staying makes it double: The value of licensing recorded music online. Journal of Cultural Economics, 40(3), 227-259.

Hansen, T. B. (1997). The willingness-to-pay for the Royal Theatre in Copenhagen as a public good. Journal of Cultural Economics, 21(1), 1-28.

Hardy, W. (2013). How to Perfectly Discriminate in a Crowd? A Theoretical Model of Crowdfunding. Working Papers 16/2013 (101). Warszawa, Poland: University of Warsaw, Faculty of Economic Sciences.

Harrison, R. (2013). Crowdfunding and the revitalisation of the early stage risk capital market: Catalyst or chimera? Venture Capital, 15(4), 283-287.

Hobbs, J., Grigore, G., \& Molesworth, M. (2016). Success in the Management of Crowdfunding Projects in the Creative Industries. Internet Research, 26(1), 146-166.

Hudik, M., \& Chovankuliak, R. (2018). Private provision of public goods via crowdfunding. Journal of Institutional Economics, 14(1), 23-44.

Indiewire (2017). Kickstarter and Sundance: The Biggest Success Stories of the Last 6 Years. https:// www.indiewire.com/gallery/kickstarter-six-years-sundance-crowdfunding-success-stories/10worldoftomorrow-bitter-films/. Accessed 05 Dec 2021. 
Josefy, M., Dean, T., Albert, L., \& Fitza, M. (2016). The role of community in crowdfunding success: Evidence on cultural attributes in funding campaigns to "Save the Local Theater." Entrepreneurship Theory and Practice, 41(2), 161-182.

Kim, P. H., Buffart, M., \& Croidieu, G. (2016). TMI: Signaling credible claims in crowdfunding campaign narratives. Group \& Organization Management, 41(6), 717-750.

Klamer, A. (2016). The value-based approach to cultural economics. Journal of Cultural Economics, 40(4), 365-373.

Kretschmer, M., Klimis, G. M., \& Choi, C. J. (1999). Increasing returns and social contagion in cultural industries. British Journal of Management, 10(s1), 61-72.

Kuppuswamy, V., \& Bayus, B. L. (2013). Crowdfunding creative ideas: the dynamics of projects backers in kickstarter. UNC Kenan-Flagler Research paper no. 2013-15.

Kuppuswamy, V., \& Bayus, B. L. (2017). Does my contribution to your crowdfunding project matter? Journal of Business Venturing, 32(1), 72-89.

Kuppuswamy, V., \& Bayus B. L. (2018). Crowdfunding creative ideas: The dynamics of project backers. In Cumming D., \& Hornuf L. (Eds.) The economics of crowdfunding. Palgrave Macmillan, Cham. https://doi.org/10.1007/978-3-319-66119-3_8.

Lazzaro, E., \& Noonan, D. (2020). A comparative analysis of US and EU regulatory frameworks of crowdfunding for the cultural and creative industries. International Journal of Cultural Policy. https://doi.org/10.1080/10286632.2020.1776270?needAccess=true

Liebowitz, S. J., \& Watt, R. (2006). How best to ensure remuneration for creators in the market for music? Copyright and Its Alternatives. Journal of Economic Surveys, 20(4), 513-545.

Luo, H. (2014). When to sell your idea: Theory and evidence from the movie industry. Management Science, 60(12), 3067-3086.

Marom, D., Robb, A., \& Sade, O. (2016). Gender dynamics in crowdfunding (Kickstarter): Evidence on entrepreneurs, investors, deals and taste-based discrimination. http://utahwfc.org/uploads/2015_ 08a.pdf

Martin, F. (1994). Determining the size of museum subsidies. Journal of Cultural Economics, 18(4), 255-270.

McAfee, R. P., McMillan, J., \& Whinston, M. D. (1989). Multiproduct monopoly, commodity bundling, and correlation of values. The Quarterly Journal of Economics, 104(2), 371-383.

Mendes-Da-Silva, W., Rossoni, L., Conte, B. S., Gattaz, C. C., \& Francisco, E. R. (2016). The impacts of fundraising periods and geographic distance on financing music production via crowdfunding in Brazil'. Journal of Cultural Economics, 40(1), 75-99.

Mollick, E. (2014). The dynamics of crowdfunding: An exploratory study. Journal of Business Venturing, 29(1), 1-16.

Mollick, E., \& Nanda, R. (2016). Wisdom or madness? Comparing crowds with expert evaluation in funding the arts. Management Science, 62(6), 1533-1553.

Moritz, A., \& Block, J. H. (2016). Crowdfunding: A literature review and research directions. In D. Brüntje \& O. Gajda (Eds.), Crowdfunding in Europe. Heidelberg: Springer.

Nelson, P. (1970). Information and consumer behavior. Journal of Political Economy, 78(2), 311-329.

Noonan, D. S. (2003). Contingent valuation and cultural resources: A meta-analytic review of the literature. Journal of Cultural Economics, 27(3-4), 159-176.

Parhankangas, A., \& Renko, M. (2017). Linguistic style and crowdfunding success among social and commercial entrepreneurs. Journal of Business Venturing, 32(2), 215-236.

Plottu, E., \& Plottu, B. (2007). The concept of total economic value of environment: A reconsideration within a hierarchical rationality. Ecological Economics, 61(1), 52-61.

Potts, J., Cunningham, S., Hartley, J., \& Ormerod, P. (2008). Social network markets: A new definition of the creative industries. Journal of Cultural Economics, 32(3), 167-185.

Regner, T. (2020). Crowdfunding a monthly income: An analysis of the membership platform Patreon. Journal of Cultural Economics. https://doi.org/10.1007/s10824-020-09381-5

Rosen, S. (1981). The economics of superstars. The American Economic Review, 71(5), 845-858.

Runge, C. F. (1984). Institutions and the free rider: The assurance problem in collective action. The Journal of Politics, 46(1), 154-181.

Rykkja, A., Munim, Z. H., \& Bonet, L. (2020). Varieties of cultural crowdfunding: The relationship between cultural production types and platform choice. Baltic Journal of Management, 15(2), 261-280.

Rysman, M. (2009). The economics of two-sided markets. Journal of Economic Perspectives, 23(3), $125-143$. 
Seaman, B. A. (2020). Economic impact of the arts. In Towse, R. and Navarrete, T. (eds.), Handbook of cultural economics, 3rd edn. Cheltenham: Edward Elgar Publishing.

Seaman, B. A. (1981). Economic theory and the positive economics of arts financing. American Economic Review, 71(2), 335-340.

Seaman, B. A. (2006). Empirical studies of demand for the performing arts. In V. Ginsburgh \& C. D. Throsby (Eds.), Handbook on the economics of art and culture (pp. 415-472). Elsevier.

Senabre, E., \& Morell, M. (2018). Match-funding as a formula for crowdfunding: A case study on the Goteo.org Platform. In Proceedings of the 14th international symposium on open collaboration, 1-5. https://doi.org/10.1145/3233391.3233967.

Shi, W. S. (2018). Crowdfunding: Designing an effective reward structure. International Journal of Market Research, 60(3), 288-303.

Shneor, R., \& Vik, A. A. (2020). Crowdfunding success: a systematic literature review 2010-2017. Baltic Journal of Management, 15, 149-182.

Smith, S., Windmeijer, F., \& Wright, E. (2013). Peer effects in charitable giving: Evidence from the (running) field. The Economic Journal, 125(585), 1053-1071.

Stemler, A. (2013). The JOBS Act and crowdfunding: Harnessing the power -and money - of the masses. Business Horizons, 56(3), 271-275.

Swords, J. (2017). Crowd-patronage-Intermediaries, geographies and relationships in patronage networks. Poetics, 64, 63-73.

Tabarrok, A. (1998). The private provision of public goods via dominant assurance contracts. Public Choice, 96(3-4), 345-362.

Throsby, D. (1994). The production and consumption of the arts: A view of vultural economics. Journal of Economic Literature, 32(1), 1-29. http://www.jstor.org/stable/2728421.

Throsby, D. (2001). Economics and culture. Cambridge, UK: Cambridge University Press.

Throsby, D. (2003). Determining the value of cultural goods: How much (or how little) does contingent valuation tell us? Journal of Cultural Economics, 27(3-4), 275-285.

Towse, R. (1997). The monopolies and mergers commission's investigation of the UK music market. Journal of Cultural Economics, 21(2), 147-151.

Towse, R. (2001). Partly for the money: Rewards and incentives to artists. Kyklos, 54(2-3), 473-490.

Towse, R., Handke, C., \& Stepan, P. (2008). The economics of copyright law: A stocktake of the literature. Review of Economic Research on Copyright Issues, 5(1), 1-22.

van de Rijt, A., Kang, S. M., Restivo, M., \& Patil, A. (2014). Field experiments of success-breeds-success dynamics. Proceedings of the National Academy of Sciences, 111(19), 6934-6939.

Varian, H. R. (2005). Copying and copyright. The Journal of Economic Perspectives, 19(2), 121-138.

Viotto da Cruz, J. (2018). Beyond financing: Crowdfunding as an informational mechanism. Journal of Business Venturing, 33(3), 371-393.

Vismara, S. (2018). Signalling to Overcome Inefficiencies in Crowdfunding Markets. In: Cumming D., \& Hornuf L. (Eds.) The Economics of Crowdfunding. Palgrave Macmillan.

De Voldere, I., \& Zeqo, K. (2017). Crowdfunding Reshaping the crowd's engagement in culture. Luxembourg: Publications Office of the European Union. Retrieved from: https://europa.eu/capacity4d ev/crowdfunding/documents/new-report-crowdfunding-reshaping-crowds-engagement-culture. Accessed 20 November 2020.

Waldfogel, J. (2012a). Copyright protection, technological change, and the quality of new products: Evidence from recorded music since Napster. The Journal of Law and Economics, 55(4), 715-740.

Waldfogel, J. (2012b). Copyright research in the digital age: Moving from piracy to the supply of new products. American Economic Review, 102(3), 337-342.

Waldfogel, J. (2017). How digitization has created a golden age of music, movies, books, and television. Journal of Economic Perspectives, 31(3), 195-214.

Walthoff-Borm, X., Schwienbacher, A., \& Vanacker, T. (2018). Equity crowdfunding: First resort or last resort? Journal of Business Venturing, 33(4), 513-533.

Watercutter, A. (2013). Why People Get Annoyed at Celebrities on Kickstarter (and Why They Probably Shouldn't). Wired, 30 April 2013. Online: https://www.wired.com/2013/04/zach-braff-kickstarter/

Younkin, P., \& Kashkooli, K. (2016). What problems does crowdfunding solve? California Management Review, 58(2), 20-43.

Zhang, H., \& Chen, W. (2019). Backer motivation in crowdfunding new product ideas: Is it about you or is it about Me? Journal of Product Innovation Management, 36(2), 241-262.

Zheng, H., Li, D., Wu, J., \& Xu, Y. (2014). The role of multidimensional social capital in crowdfunding: a comparative study in China and US. Information \& Management, 51(4), 488-496. 
Ziegler, T., Shneor, R., Garvey, K., Wenzlaff, K., Yerolemou, N., Zhang, B.\& Hao, R. (2018). Expanding Horizons: The 3rd. European Alternative Finance Industry Report. Cambridge, UK: Cambridge Center for Alternative Finance. Available online: https://www.jbs.cam.ac.uk/fileadmin/user_ upload/research/centres/alternative-finance/downloads/2018-ccaf-exp-horizons.pdf. Accessed 3 May 2019.

Ziegler, T., Shneor, R., Wenzlaff, K., Kim, J., Paes, F. F. D. C., Suresh, K. (2021). The global alternative finance market benchmarking report. Cambridge: Cambridge Center for Alternative Finance. Available online: https://www.jbs.cam.ac.uk/faculty-research/centres/alternative-finance/publicatio ns/the-2nd-global-alternative-finance-market-benchmarking-report/. Accessed 25 Aug 2021.

Zvilichovsky, D., Yael, I., \& Barzilay, O. (2015). Playing both sides of the market: success and reciprocity on crowdfunding platforms. Available on SSRN: https://papers.ssrn.com/abstract=2304101. Accessed 11 Dec 2020.

Publisher's Note Springer Nature remains neutral with regard to jurisdictional claims in published maps and institutional affiliations. 